\title{
PENYELENGGARAAN EFSD DALAM JALUR PENDIDIKAN DI INDONESIA
}

\author{
1)Yanti Shantini \\ 1 adalah Dosen Jurusan Pendidikan Luar Sekolah Fakultas Ilmu Pendidikan \\ Email: yanti.shantini@gmail.com
}

\begin{abstract}
Abs tract
Education for Sustainable Development has long been known in Indonesia known by the name of Education for Sustainable Development. During this time partially understood its implementation so as not to build synergy in promoting physical development towards social welfare. In this article described how the implementation of education for sustainable development in terms of three lines of education in Indonesia. Each track has a unique contribution and a different role for the progress of the nation .
\end{abstract}

Keyword : ESD , access to education, social welfare.

\section{PENDAHULUAN}

Berbagai langkah upaya dan pendekatan dalam melestarikan pembangunan Indonesia di masa depan. Kesadaran akan pembangunan berkelanjutan (sustainable development) menjadikan keterikatan akan kepedulian pada daya dukung sistem alam dengan tantangan sosial yang dihadapi oleh umat manusia pada umumnya dan warga Negara Indonesia pada khususnya.

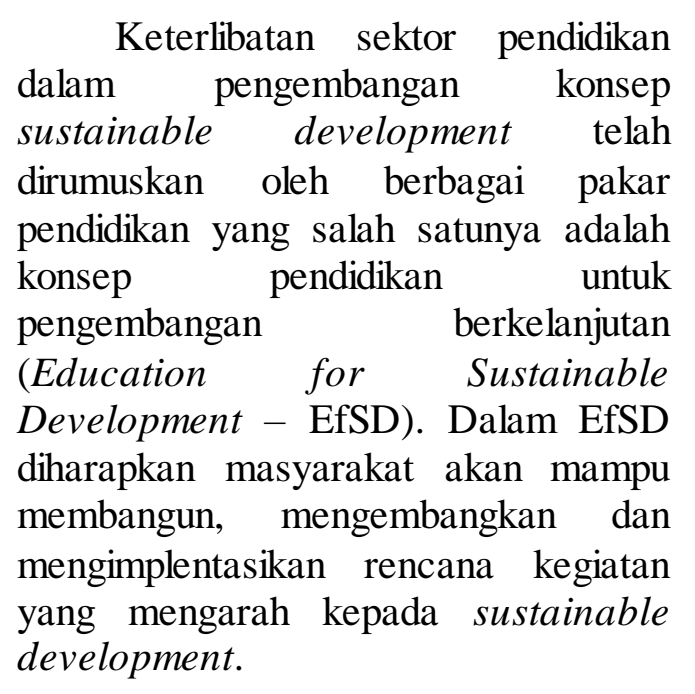

lingkungan hidup dilakukan untuk menjaga keberlangsungan .

Kebijakan yang diambil oleh pemerintah Indonesia dalam pembangunan berkelanjutan dilakukan dengan memberikan pemahaman keterampilan dan menanamkan nilainilai untuk hidup berkelanjutan dalam masyarakat. Namun pada kenyataannya penerapan sustainable development di Indonesia masih belum maksimal yang ditunjukkan oleh adanya penurunan pada bidang pertanian lingkungan baik secara kuantitas maupun kualitas sebagai akibat dari belum selarasnya pemahaman pemerintah dalam implementasi sustainable development.

Kegagalan dalam implementasi pembangunan berkelanjutan di Indonesia sebagian besar banyak dipengaruhi oleh faktor ekonomi sehingga kelestarian lingkungan tidak menjadi prioritas utama atau bahkan diabaikan oleh masyarakat. Untuk itu pemahaman akan pembangunan 
berkelanjutan perlu terus dilakukan agar pengembangan yang dilakukan tidak mengurangi kemampuan generasi mendatang untuk memenuhi kebutuhannya sendiri.

Pengenalan pendidikan untuk pembangunan berkelanjutan (EFSD) dapat dilaksanakan melalui berbagai jalur dalam pendidikan di Indonesia, dengan sasaran yang bervariasi dimulai dari masyarakat di perkotaan, pedesaan ataupun pesisir. Sebagai upaya memberikan penyadaran dan kemampuan kepada semua orang terutama generasi mendatang untuk berkontribusi lebih baik bagi pengembangan berkelanjutan pada masa sekarang dan yang akan datang.

Keterbatasan akses dan layanan pendidikan di pedesaan menjadikan pengenalan EfSD menjadi suatu program yang sangat penting untuk dipahami oleh pelaku pembangunan di tingkat nasional maupun regional. Pembangunan yang memiliki tujuan untuk meningkatkan kesejahteraan masyarakat banyak ditentukan oleh aktivitas manusia sebagai pelaku pembangunan. Giarci (2001) memandang community development sebagai suatu hal yang memiliki pusat perhatian dalam membantu masyarakat pada berbagai tingkatan umur untuk tumbuh dan berkembang melalui berbagai fasilitasi dan dukungan agar mereka mampu memutuskan, merencanakan dan mengambil tindakan untuk mengelola dan mengembangkan lingkungan fisiknya serta kesejahteraan sosialnya. Proses ini berlangsung dengan dukungan collective action dan networking yang dikembangkan masyarakat.
Setelah kesadaran akan collective action telah terpenuhi menjadikan masyarakat semakin komplek dan kuat. Sehingga menurut Subejo dan Supriyanto (2004) masyarakat mencapai suatu tingkat keberdayaan dalam merencanakan, memutuskan danmengelola sumberdaya lokal yang dimiliki melalui collective action dannetworking sehingga pada akhirnya mereka memiliki kemampuan dan kemandirian secara ekonomi, ekologi, dan sosial".

Untuk itu memahami konsep EfSD tidak hanya mengkaji aspek lingkungan sebagai suatu bagian dalam pembangunan di Indonesia namun para fasilitator pembangunan perlu memahami aspek-aspek dalam pembangunan berkelanjutan yaitu pertama, keberlanjutan ekologi yaitu dengan memelihara keberlanjutan biomass sehingga melewati daya dukungnya, kedua, keberlanjutan sosial ekonomi yaitu dengan memperhatikan kesejahteraan masyarakat, ketiga adalah keberlangsungan masyarakat sebagai pelaku dari pembangunan.

\section{PEMBAHASAN}

\section{Pendidikan untuk Pembangunan Berkelanjutan (EfSD)}

Selama ini kita telah mengenal konsep pembangunan berkelanjutan sebagai suatu pendekatan dalam meningkatkan kesejahteraan umat manusia tanpa mengesampingkan pemeliharaan lingkungan oleh individu yang memanfaatkan alam 
sebagai sumberdayanya. Kesadaran akan keterbatasan sumberdaya alam secara kuantitas dan kualitas membutuhkan pengelolaan sumberdaya alam yang baik dan bijaksana.

Namun seperti yang telah dijelaskan sebelumnya seringkali program pembangunan yang dirancang dan diselenggarakan dengan tujuan untuk meningkatkan kesejahteraan semata tanpa mempertimbangkan aspek lingkungan sebagai bagian dari pembangunan tersebut. Hal ini masuk akal karena para perancang program pembangunan memperhatikan aspek keberdayaan masyarakat yaitu kemampuan dari dari masyarakat untuk meningkatkan kesejahteraan dirinya dengan memanfaatkan potensi yang ada disekitarnya.

Untuk itu perlu dibekalinya para perancang program akan wawasan mengenai EfSD dalam merancang program pemberdayaan di masyarakat, sehingga nantinya diharapkan telah terjadi kesinambungan antara program ekonomi dan pemeliharaan lingkungan dalam kegiatan pemberdayaan masyarakat pada kelompok sasaran.

\section{a. Pengertian Pendidikan Untuk Pembangunan Berkelanjutan}

Istilah EfSD berasal dari istilah Education Sustainable Development atau di singkat ESD minus for atau Pendidikan Pengembangan

Berkelanjutan tanpa memakai kata untuk. Mengapa di Indonesia ditambah dengan for atau untuk. Kata untuk berarti menghasilkan sesuatu, ada tujuan yang ingin dicapai. Untuk menghasilkan sesuatu atau mencapai tujuan, harus ada tindakan (action). Sedangkan development diterjemahkan pengembangan bukan pembangunan, karena pembangunan sering dimaknai pembangunan fisik atau infrastruktur (Hastuti, 2009).

Pengertian EfSD di atas memberikan arahan yang kerap menjadi kebingungan bagi para perancang pembangunan dimana pengertian sustainable development kerap diartikan sebagai pembangunan secara fisik atau infrastruktur. Hal menyulitkan bagi para perancang pembangunan di tingkat regional dalam mengimplementasikan pembangunan berkelanjutan sebagai suatu konten dalam pembangunan yang mengemban misi untuk meningkatkan kesejahteraan yang berbasis lingkungan.

Untuk itu Pendidikan untuk Pengembangan Berkelanjutan atau Education for Sustainable Development (EfSD) menurut Kemendiknas diartikan sebagai pendidikan yang secara esensial menyisipkan wawasan dan konsep secara luas, mendalam, dan futuristik tentang lingkungan global. Konsep EfSD adalah pendidikan untuk mendukung pengembangan berkelanjutan, yaitu pendidikan yang memberi kesadaran dan kemampuan kepada semua orang terutama generasi mendatang untuk berkontribusi lebih baik bagi pengembangan berkelanjutan pada masa sekarang dan yang akan datang (Kementerian Pendidikan Nasional, 2010).

Berdasarkan paradigma baru dalam pendidikan Sudibyo (2009) menjelaskan EfSD dalam jalur pendidikan di Indonesia dilaksanakan dalam jalur formal, nonformal dan informal. Ketiga jalur ini memiliki sasaran dan pola pengembangan yang berbeda sesuai dengan target capaian dalam pembangunan yang mempertimbangkan 3 dimensi yaitu 
kesinambungan ekonomi, keadilan sosial (termasuk kultur dan budaya), dan kelestarian lingkungan secara simultan, seimbang dan berkelanjutan.

b. Penyelenggaraan EfSD dalam 3 Jalur Pendidikan di Indonesia Penyelenggaraan pendidikan di Indonesia diatur dalam Undangundang Sistem Pendidikan Nasional No. 20 tahun 2003 yang mengatur layanan pendidikan di Indonesia diselenggarakan dalam tiga jalur yaitu jalur pendidikan formal, non formal dan informal. Di dalam undang undang tersebut dijelaskan bahwa pendidikan formal adalah jalur pendidikan yang terstruktur dan berjenjang yang terdiri atas pendidikan dasar, pendidikan menengah, dan pendidikan tinggi. Sedangkan pendidikan nonformal adalah jalur pendidikan di luar pendidikan formal yang dapat dilaksanakan secara terstruktur dan berjenjang. Pendidikan informal adalah jalur pendidikan keluarga dan lingkungan.

\section{1) Pengenalan EfSD dalam Pendidikan Formal}

Pendidikan formal yang memiliki karakteristik jenjang, keberaturan dan kemapanan memberikan arahan yang jelas dalam mengimplementasikan EfSD di pendidikan persekolahan dimulai dari prasekolah, pendidikan dasar, menengah dan tinggi. Keterpaduan EfSD dalam kurikulum di persekolahan dinyatakan dalam penetapan mata pelajaran Lingkungan Hidup di tingkat SD, SLTP dan SLTA. Dalam mengimplementasikan pendidikan yang mendukung pembangunan berkelanjutan pada jalur pendidikan formal tersebut dikembangkan dan diarahkan pada upaya penanaman nilai-nilai pembangunan semenjak dini melalui pembelajaran di sekolah yang mengarah pada keberlanjutan pembangunan ekonomi, ekologi dan sosial budaya.

$$
\text { Menurut Sudibyo (2009) }
$$

kegiatan yang dilakukan dalam pembelajaran di sekolah adalah pengembangan dalam dimensi lingkungan. Dimensi lingkungan menitikberatkan pada pada upaya menanamkan kesadaran dan tanggungjawab siswa secara sendirisendiri atau bersama menciptakan lingkungan yang bersih, sehat dan nyaman dengan membudayakan perilaku green dalam aktivitas keseharian:

- Penghijauan/menanam pohon di panti belajar dan sekitarnya, di pekarangan rumah dan sekitarnya, lahan tidak produktif.

- Menjaga kebersihan tempat belajar dan sekitarnya, rumah dan sekitarnya (sanitasi air, MCK, bak sampah).

- 3 M (menguras bak mandi, mengubur kaleng-kaleng bekas, membakar sampah)

- Membuang sampah pada tempatnya

- Tidak menggunakan bahan kimia (pengawet, pewarna) pada makanan

- Budidaya obat-obatan herbal

- Tidak menebang pohon seenaknya

- Tidak membunuh binatang seenaknya

- Tidak memeliharan binatang yang dilindungi.

- Reuse 
- Menggunakan sisi lain kertas yang sudah dipakai untuk memo, mencetak hasil pekerjaan yang belum fix, menggunakan amplop dari kertas bekas.

- Menggunakan kantong plastik bekas setiap belanja sehingga tidak perlu membeli baru.

- Reduce

- Menghemat air

- Mematikan perangkat elektronik yang tidak dipakai.

- Membatasi penggunaan semua barang elektronik.

- Mematikan lampu

- Mematikan AC mobil untuk perjalanan jarak dekat

- Recycle

- Mengolah sampah organik rumah tangga menjadi kompos.

- Mengolah limbah plastik menjadi aneka kerajinan

- Mengolah kotoran ternak menjadi kompos, biogas

- Mengolah limbah kopi menjadi pewarna alami batik

- Memanfaatkan serbuk gergaji menjadi media jamur tiram

- Pemanfaatan kain perca untuk aneka produk

- Pengurangan polutan:

- Tidak membuang limbah/sampah di sungai

- Tidak menggunakan pupuk kimia untuk pertanian dan perkebunan

- Penghijauan

- Biodeversitas
- Pengurangan emisi

- Mengganti minyak tanah atau LPG dengan biogas, bioetanol

- Mengganti solar dengan biodiesel

- Mengganti tenaga listrik dengan tenaga surya, tenaga angin

Kegiatan-kegiatan tersebut di atas menjadi bentuk refensi akan kegiatan ataupun wawasan pengelolaan lingkungan yang perlu diketahui oleh siswa sekolah di tingkat dasar hingga tinggi dalam berpartisipasi

2) Pengenalan EfSD dalam Jalur Pendidikan Non Formal Penyelenggaraan pendidikan non formal di Indonesia diselenggarakan dalam satuan satuan pendidikan meliputi kelompok belajar, kursus dan pelatihan, majelis taqlim, PKBM dan satuan pendidikan sejenis. Dalam setiap satuan menyelenggarakan program sesuai dengan kebutuhan dan kondisi masyarakat sasaran.

Dalam mengenalkan program EfSD dalam jalur pendidikan non formal dapat dilaksanakan melalui kegiatan akademik melalui proses pembelajaran seperti dalam program PAUD yaitu kelompok bermain dan TPA, program keaksaraan, program kesetaraan dan lain sebagainya. Pendidikan untuk Pengembangan Berkelanjutan dapat pula dilaksanakan melalui pendidikan keterampilan sebagai program pemberdayaan masyarakat seperti dalam program life skill, kewirausahaan, kursus keterampilan dan lain sebagainya.

$$
\text { Menurut Sudibyo }
$$
pengenalan EfSD dimensi ekonomi diperkenalkan melalui ketrampilan 
produktif yang dikembangkan sangat tergantung potensi sumber daya alam yang ada:

- Untuk daerah pegunungan atau pedesaan, usaha produktif dapat berupa budi daya pertanian (sayuran, buah- buahan, palawija, ubi-ubian, tanaman obat), perkebunan, pesawahan, peternakan, perikanan, pertukangan dan home industri yang sifatnya pengolahan pasca panen, agrowisata, wisata alam.

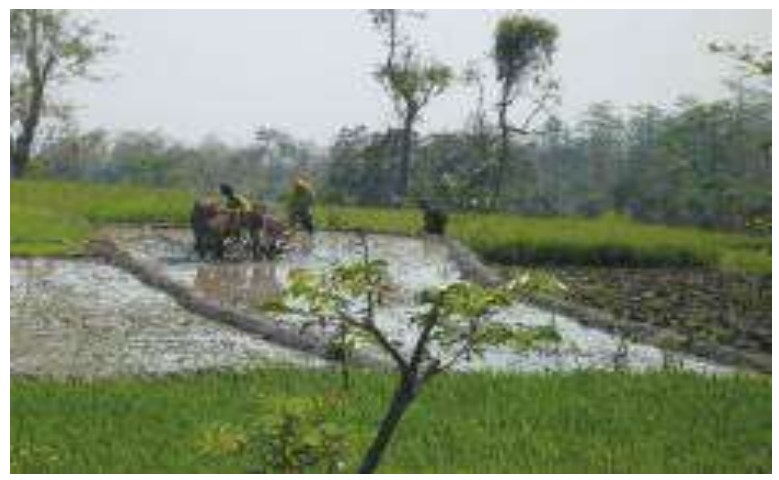

Gambar 1

Budidaya Padi

- Untuk daerah pesisir misalnya budidaya terkait potensi laut seperti rumput laut, mutiara, perikanan, dan home industri pasca panen seperti pengasapan ikan, pengalengan ikan, aneka kerajinan dari kerang, aneka kerupuk berbahan dasar ikan laut, petis, wisata alam.

- Untuk perkotaan, pengembangan usaha lebih banyak bersifat jasa seperti elektro seperti (teknisi dan operator komputer, teknisi hp, servis televisi, AC, kulkas), security, perhotelan, SPA, otomotif, salon kecantikan, perawatan binatang piaraan, pertamanan, baby sitter, binatu, aerobik, fitness, yoga, montir, pertukangan, garmen, las, refleksi. Usaha yang bersifat produksi misalnya boga, tanaman hias, ikan hias, mebelair.

Berbagai bentuk pendidikan keterampilan tersebut di atas dapat diselenggarakan dalam pendidikan nonformal yang mengintegrasikan pengelolaan lingkungan dengan kegiatan usaha yang dikembangkan oleh masyarakat.

\section{3) Pengenalan EfSD dalam} Jalur Pendidikan InFormal

Jalur ketiga dalam pendidikan di Indonesia yang memberikan layanan pendidikan bagi masyarakat adalah satuan terkecil dari masyarakat sendiri yaitu keluarga. Keluarga memiliki keleluasaan dan keunikan dalam memberikan layanan pendidikan kepada anggota keluarganya terutama dalam memperkenalkan nilai-nilai keluarga ataupun budaya dalam masyarakat dimana keluarga tersebut tinggal. 


\begin{abstract}
Menurut Sudibyo (2009) memperkenalkan pendidikan untuk pengembangan berkelanjutan pada tataran keluarga terutama dalam pengembangan aspek sosial budaya yang pada intinya adalah upaya menjaga, mengembangkan sistem nilai, budaya, adat-istiadat, normanorma yang sudah baik yang berlaku di masyarakat dan membawa perubahan-perubahan pada hal-hal yang kurang baik.
\end{abstract}

- Memelihara sistem nilai yang berlaku di masyarakat (gotong royong, kerjasama, rukun, guyub, kekerabatan, saling keterbukaan, empati yang tinggi, solidaritas sosial)

- Memelihara adat istiadat yang tidak melanggar normanorma susila, norma agama dan hukum seperti selapanan, nujuh bulanan, nyadran, sekatenan, grebeg besar, Kenduri/selamatan dsb

- Memperbaiki pola perilaku masyarakat yang irasional, menyimpang dan kontra produktif seperti pergi kedukun ketika sakit, percaya pada bendabenda tertentu (aji-aji/jimat, keris, cincin, batu), judi, adu jago, ngerumpi.

- Memelihara seni tradisional

- Mengembangkan budaya menghargai pluralistik.

- Mengembangkan demokrasi

- Mengganti budaya kekerasan (premanisme) dengan budaya harmoni

- Mengembangkan budaya antri

Adanya keterlibatan anggota keluarga sebagai bagian dari pment disajikan sebagai berikut: komunitas dalam melestarikan budaya dan lingkungan sekitarnya sejalan dengan konsep EfSD yang diartikan sebagai konsep dinamis yang mencakup sebuah visi baru pendidikan yang mengupayakan pemberdayaan setiap orang dari segala usia untuk turut bertanggungjawab dalam menciptakan masa depan yang berkelanjutan (KTT Dunia untuk Pengembangan Berkelanjutan, 2002 dalam Hastuti, 2009).

\section{Keterkaitan Pembangunan Masyarakat dan Pembangunan Berkelanjutan \\ Pemberdayaan masyarakat} memiliki keterkaitan erat dalam sustainable development dimana pemberdayaan masyarakat merupakan suatu prasyarat utama serta dapat diibaratkan sebagai gerbong yang akan membawa masyarakat menuju suatu keberlanjutan secara ekonomi, sosial, dan ekologi yang dinamis.

Lingkungan strategis yang dimiliki oleh masyarakat lokal antara lain mencakup lingkungan produksi, ekonomi, sosial dan ekologi. Melaluiupaya pemberdayaan, warga masyarakat didorong agar memiliki kemampuan untuk memanfaatkan sumberdaya yang dimilikinya secara optimal serta terlibat secara penuh dalam mekanisme produksi, ekonomi, social dan ekologi-nya. Secara ringkas keterkaitan antara pemberdayaan masyarakat dengan sustainable develo 


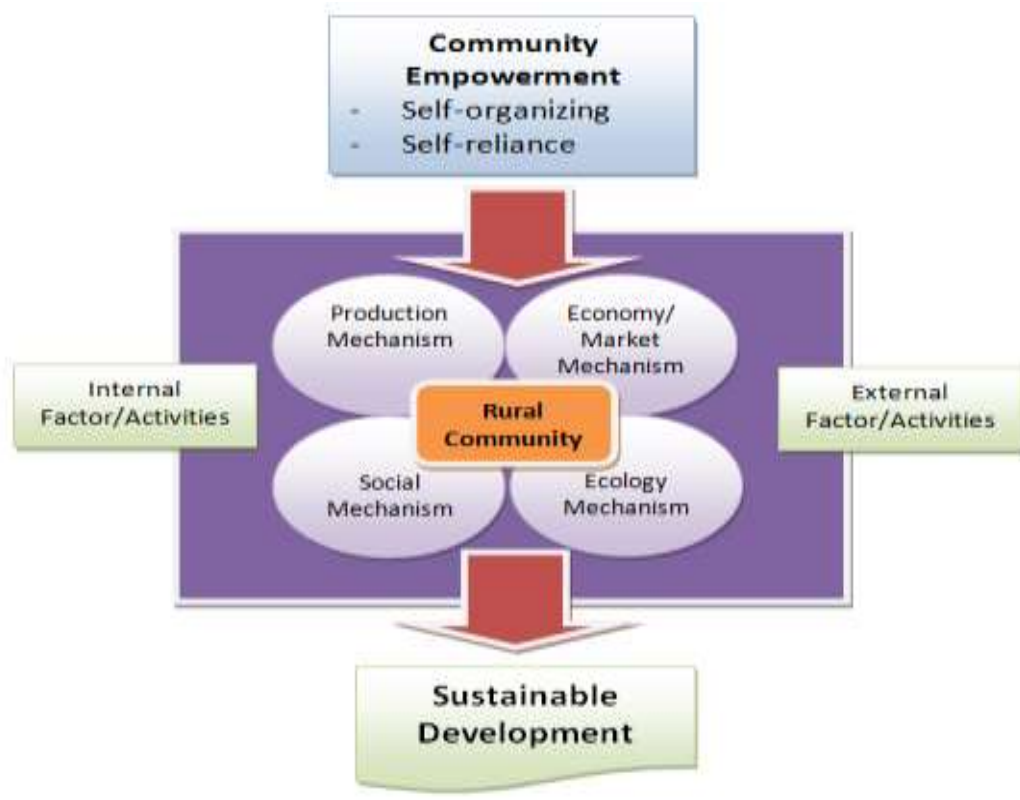

Bagan 1

Keterkaitan antara Pemberdayaan Masyarakat dengan Pembangunan Berkelanjutan Sumber: Suprianto dan Subejo (2004)

Pelaksanaan pembangunan berkelanjutan di daerah pedesaan didasari oleh upaya pemberdayaan warga masyarakat untuk memiliki kemampuan untuk memanfaatkan sumberdaya yang dimilikinya disekitarnya secara optimal. Optimalisasi pemberdayaan tersebut dapat dicapai apabila warga masyarakat mengenal potensi dan kelemahan yang dimilikinya serta kesempatan dan tantangan yang dapat diraih dalam mencapai keberdayaanya.

\section{Pihak yang Te rlibat dalam EfSD}

\section{a. Sasaran Utama}

Pembangunan Berkelanjutan

Masyarakat dipandang sebagai pihak yang paling mengetahui tentang segala sesuatu yang dalam diri dan lingkungannya. Anggota masyarakat memiliki pengalaman dari masyarakat tersebut, tentang kebutuhan dan masalah-masalahnya, kekuatan dan kelebihannya, serta ciri-ciri khasnya (Ife \& Tesoriero, 2008:242).

Proses community development tidak bisa terlepas dari adanya pelibatan masyarakat dalam setiap langkahnya. Dalam proses community development, pemenuhan prasyarat untuk berpartisipasi harus diupayakan oleh pelaksana perubahan. Masyarakat harus diberi kekuatan dan lingkungan yang kondusif untuk dapat berpartisipasi. Hal ini dilakukan melalui pengkondisian secara simultan sebagai rangkaian dari proses pembangunan di lingkungannya.

\section{b. Pihak-Pihak yang Terlibat dalam Pembangunan \\ Berkelanjutan}

$\begin{array}{lrr}\text { Sejalan } & \text { dengan } & \text { konsepsi } \\ \text { pembangunan nasional } & \text { yang } \\ \text { menggariskan bahwa "pembangunan } \\ \text { desa dan masyarakat desa diarahkan } \\ \text { untuk mendorong r tumbuh }\end{array}$


kembangnya prakarsa dan swadaya masyarakat. Kemampuan masyarakat desa perlu didukung dan ditingkatkan baik melalui penataan kelembagaan, perluasan atau diversifikasi usaha dengan tujuan agar mereka semakin mampu mengarahkan dan memanfaatkan dana serta daya bagi peningkatan pendapatan dan taraf hidupnya.

Bertolak dari konsepsi diatas, pembangunan perdesaan memang harus diletakkan dalam kerangka pembangunan yang berkelanjutan. Hal tersebut mengingat karena selain akan mengejar peningkatan kondisi sosial ekonomis, juga karena corak kehidupan dan penataan masyarakat desa sangat beranekaragam.

Dasar-dasar pembangunan perdesaan selalu mempertimbangkan faktor sosial ekonomis yang merupakan faktor pembentuk kehidupan masyarakat desa. Dasardasar tersebut umumnya banyak ditentukan oleh keadaan geografis, profesi kehidupan yang berkembang, serta beberapa faktor lain yang timbul dari pengaruh lingkungan yang luas seperti halnya hubungan kota besar dan daerah perdesaan (Biro Pusat Statistik, 1986).

Untuk itu fasilitator

pembangunan masyarakat di pedesaan perlu mengetahui pihakpihak yang memiliki potensi dan kepentingan dalam pembangunan di pedesaan. Secara garis besar terdapat 3 pihak yang memiliki kontribusi atau peran dalam setiap kegiatan pembangunan di pedesaan yaitu pemerintah pusat, pemerintah daerah dan fasilitator masyarakat.

\section{1) Pemerintah Pusat}

Kebijakan pembangunan yang dilakukan pemerintah dituangkan dalam tiga arah kebijakan, yaitu tidak langsung, langsung dan khusus. Kebijakan tidak langsung diarahkan pada penciptaan kondisi yang menjamin kelangsungan setiap upaya penanggulangan kemiskinan. Kondisi yang dimaksudkan antara lain adalah suasana sosial politik yang tenteram, ekonomi yang stabil dan budaya yang berkembang (Boediono, 1993). Kebijakan langsung diarahkan kepada peningkatan peranserta dan produktivitas sumberaya manusia, khususnya golongan masyarakat berpendapatan rendah, melalui penyediaan kebutuhan dasar berupa pangan, sandang, perumahan, kesehatan dan pendidikan, serta pengembangan kegiatan sosial ekonomi yang berkelanjutan untuk mendorong kemandirian golongan masyarakat berpendapatan rendah. Sedangkan kebijakan khusus adalah mempersiapkan masyarakat dan meningkatkan kemampuan aparat daerah yang bertanggung jawab langsung dalam merencanakan, melaksanakan dan memantau pelaksanaan program-program pembangunan, dan sekaligus memacu dan memperluas upaya untuk meningkatkan pemerataan pembangunan dan penanggulangan kemiskinan. Kebijakan ini dilaksanakan secara terpilih sesuai dengan kebutuhan masyarakat dan kesiapan aparat daerah setempat (Chenery, Hollis and Moises Syrquin, 1973).

Dalam kaitannya dengan pembangunan masyarakat desa program pemerintah pusat langsung diarahkan kepada peningkatan peranserta dan produktivitas sumber 
daya manusia khususnya golongan masyarakat berpendapatan rendah melalui penyediaan kebutuhan dasar. Pemenuhan kebutuhan dasar ini akan memberikan peluang bagi penduduk miskin untuk melakukan kegiatan sosial ekonomi yang dapat memberikan pendapatan yang memadai. Dalam kaitan itu pengembangan kegiatan sosial ekonomi diprioritaskan pada penduduk miskin di desa tertinggal berupa peningkatan kualitas sumberdaya manusia dan peningkatan permodalan yang didukung sepenuhnya dengan kegiatan pelatihan yang terintegrasi sejak dari kegiatan penghimpunan modal, penguasaan teknik produksi, pemasaran hasil dan pengelolaan surplus usaha.

\section{2) Pemerintah Daerah}

Program regional merupakan program pembangunan masyarakat yang dilaksanakan oleh pemerintah daerah, program regional adalah program pembangunan yang dilaksanakan dengan berorientasi pada kepentingan daerah dan untuk menyerasikan dan mempercepat pembangunan daerah. Kegiatan yang dilakukan tergantung dari kebutuhan daerah dan berorientasi pada aspirasi daerah (Kunarjo, 1987). Sasaran utama dalam program regional adalah menghilangkan kemiskinan dan menciptakan pemerataan laju pertumbuhan pembangunan antar daerah. Pembangunan daerah merupakan upaya mewujudkan tujuan mencapai kesejahteraan masyarakat setempat yang (Kristiadi, 1990) disesuaikan dengan kemampuan daerah dan kepentingan perencanaan sektoral dari bawah.

\section{3) Fasilitator Masyarakat}

Garda terdepan dalam melakukan program pemberdayaan masyarakat pada saat ini dilakukan oleh fasilitator masyarakat yang memiliki berbagai nama dan peran sesuai dengan program yang diembannya dari lembaga atau institusi pengirimnya.

Perjalanan hidup bersama dalam masyarakat memberikan pembelajaran kepada anggotanya tentang segala sesuatu yang berkaitan dengan dirinya. Masyarakat lokallah yang memiliki pengetahuan, kearifan dan keahlian, dan peran change agent atau fasilitator masyarakat adalah mendengar dan belajar dari masyarakat, bukan mengajari masyarakat tentang masalah dan kebutuhan mereka (Holland \& Blackburn, 1998).

\section{KESIMPULAN}

Upaya melestarikan lingkungan hidup telah menjadi tugas bersama dalam menjaga keberlangsungan pembangunan Indonesia di masa depan. Peran pendidikan sebagai upaya penyadaran bagi warga masyarakat memegang peranan yang penting dalam membantu masyarakat pada berbagai tingkatan umur untuk tumbuh dan berkembang melalui berbagai fasilitasi dan dukungan sehingga mampu mengelola lingkungan fisiknya dalam mencapai kesejahteraan sosialnya.

Education for Sustainable Development diartikan sebagai pendidikan yang secara esensial menyisipkan wawasan dan konsep secara luas, mendalam dan futuristik 
tentang lingkungan global. Konsep EfSD adalah pendidikan untuk mendukung pembangunan berkelanjutan, yaitu pendidikan yang memberi kesadaran dan berkemampuan kepada semua orang terutama generasi mendatang untuk berkontribusi lebih baik di masa datang.

Penyelenggaraan EfSD dalam 3 jalur pendidikan di Indonesia diselenggarakan dalam tiga jalur yaitu jalur pendidikan formal, nonformal dan informal. Dalam jalur pendidikan formal implementasi EfSD dimulai dari prasekolah, pendidikan dasar, menengah dan tinggi. Sedangkan pengenalan EfSD dalam jalur pendidikan nonformal diselenggarakan pada satuan pendidikan meliputi kelompok belajar, kursus dan pelatihan, majelis taqlim, PKBM dan satuan pendidikan sejenis. Adapun pengenalan EfSD dalam jalur informal dilakukan pada satuan terkecil dari masyarakat yaitu keluarga.

Pemberdayaan masyarakat memiliki keterkaitan erat dalam sustainable development dimana pemberdayaan masyarakat merupakan suatu prasyarat utama serta dapat diibaratkan sebagai gerbong yang akan membawa masyarakat menuju suatu keberlanjutan secara ekonomi, sosial, dan ekologi yang dinamis.

Pihak yang terlibat dalam kegiatan pembangunan di pedesaan yang dapat mengenalkan EfSD adalah pemerintah pusat, pemerintah daerah dan fasilitator masyarakat.

\section{DAFTAR REFERENSI}

Asia Good ESD Practice Project, "Buku Pedoman Pendidikan Untuk Pembangunan Berkelanjutan di Asia", Japan: Abe Osamu, 2008

Budi Sri Hastuti, "Pendidikan untuk Pengembangan Berkelanjutan (Education for Sustainable Development) dalam Perspektif PNFI". Semarang. 2009.Andragogia - Jurnal PNFI / Volume 1 / No 1 Nopember 2009

Charles D. Kleymeyer,'Cultural expression and grassroots development: cases from Latin America and the Caribbean", USA: Lynne Rienner Publishers, 1994

Emil Salim, "Partisipasi aktif masyarakat dalam pembangunan ekonomi untuk mencegah kesenjangan ekonomi dan keresahan social", Jakarta: Dewan Pimpinan Pusat Golongan Karya, 1990

Faisal Basri, "Perekonomian Indonesia: Tantangan dan Harapan Bagi Kebangkitan Indonesia",Jakarta: Erlangga, 2002

Fauzi A, "Ekonomi Sumber Daya Alam dan Lingkungan, Teori dan Aplikasi”, Jakarta: Gramedia Pustaka Utama, 2004

Giarci,G.G, "Caught in Nets: A Critical Examination of the 
Use of the Concept of "Network" in Community Development Studies", Oxford University Press, 2001, Community Development Journal Vol.36 (1): 63-71, January 2001

Herman E Daly, "Sustainable Development: From Concept and Theory to Operational Principles, in Resources, Environment, and Population: Present Knowledge and Future Options, ed". Kingsley Davis and Mikhail S. Bernstam, New York: Oxford University Press, 1991

Jim Ife\& Frank Tesoriero, "Community Development: Alternatif Pengembangan Masyarakat di Era Globalisasi”, Yogyakarta: Pustaka Pelajar, 2008

Jonny $\begin{aligned} & \text { Purba, } \\ & \text { Lingkungan } \\ & \text { Yayasan }\end{aligned}$ Obsial", Jakarta:
2005

Kementerian Pendidikan Nasional, "Panduan Peningkatan Kompetensi Pendidik dan Tenaga Kependidikan Nonformal dalam Rangka Pendidikan Untuk Pembangunan Berkelanjutan (Education for Sustainable Development) Melalui Pusat Pengembangan Pemberdayaan Pendidik dan Tenaga Kependidikan (PPPPTK)", Jakarta: Kementerian Pendidikan Nasional, 2010
Kementerian Pendidikan Nasional, "Petunjuk Teknis Pendidikan Perempuan untuk Pembangunan Berkelanjutan (EfSD)", Jakarta: Direktorat Pembinaan Masyarakat, 2011

$$
\begin{aligned}
& \text { Lynda Kelly, "Community } \\
& \text { Development: } \\
& \text { Technologyto } \\
& \text { Transformation", Thesis, } \\
& \text { Melbourne: University of } \\
& \text { Melbourne,1992, Unpublished }
\end{aligned}
$$

McCowan, L, "A social work approach to post genocide trauma recovery for the Rwandese community", Newcastle: University of Newcastle, 1996

Mubyarto, "Pengantar Ekonomi Pertanian", Jakarta: LP3ES, 1991

Perman, R., Yue Ma, James McGilvray, and Michael Common, "Natural resource and environmental economics, Third Edition", Longman: Harlow, 2003

Phil Bartle, "Key Words C of Community Development, Empowerment, Participation", [Online]. Tersedia: http://www.scn.org/ip/cds/cm p/key-c.htm), (Akses: 17 Maret 2011), 2003

Press Release BPS, "Kemiskinan Juli 2009”, [Online], Tersedia: www.bps.go.id, Akses: 29 Desember 2009 
Subejo dan Supriyanto, "Metodologi Pendekatan Pemberdayaan Masyarakat", 2004, Short paper pada Kuliah Intensif Pemberdayaan Masyarakat Pedesaan, Studyon Rural Empowerment (SORem)Dewan Mahasiswa Fak. Pertanian UGM tanggal 16 Mei 2004

Subejo dan Supriyanto, "Harmonisasi Pemberdayaan Masyarakat Pedesaan Dengan Pembangunan Berkelanjutan", 2004, Artikel diterbitkan dalam Buletin Ekstensia: Pusat Penyuluhan Pertanian Deptan RI Vol 19/Th XI/2004

Sutamihardja, "Perubahan Lingkungan Global: Program Studi Pengelolaan Sumber Daya Alam dan Lingkungan Sekolah Pascasarjana", Bogor: IPB, 2004

Retno S Sudibyo, "Education for Sustainable Development, EfSD”, Panduan untuk Pengembangan Berkelanjutan, Yogyakarta: Universitas Gajah Mada, 2009, Bahan Presentasi

Tim Deliveri, "Pemberdayaan Masyarakat dalam Praktek", [Online]. Tersedia: http://www.deliveri.org/guidel ines/how/hm_7/hm_7_summa ryi.htm.(Akses: 25 Maret 2011), 2004 